Gazi University
Journal of Science
http://dergipark.gov.tr/gujs

\title{
Color and COD Removal from Real Textile Wastewater using Nanoscale Zero-Value Iron (nZVI)
}

\author{
Ozlem TEPE* (D), Muslun Sara TUNC (D), Ozge HANAY (D) \\ Firat University, Department of Environmental Engineering, 23119, Elazı̆̆, Turkey.
}

\author{
Highlights \\ -nZVI particles were used to remove color and COD from real textile wastewater. \\ - The effects of solution $\mathrm{pH}, \mathrm{nZVI}$ dosage and temperature on the removal efficiency were investigated. \\ -This study demonstrated that nZVI can be used for efficient treatment of real textile wastewater.
}

\section{Article Info}

Received: 08 Dec 2020

Accepted: 12 Feb 2021

\section{Keywords}

Color and COD removal

Nanoscale zero-valent

iron particles (nZVI)

Real textile wastewater

Wastewater treatment

\begin{abstract}
Nanoscale zero-value iron (nZVI) has a high specific surface area and significant abilities to reduce contaminants. In this study, the removal of color and COD from real textile wastewater was studied by nZVI particles. A series of experiments were conducted to evaluate the effect of operational parameters such as solution $\mathrm{pH}$, nZVI dosage and temperature on color and COD removal. The results showed that the color and COD removals mainly depend on solution $\mathrm{pH}$. The color removal efficiencies were $96.3 \%$ at $436 \mathrm{~nm}, 97.8 \%$ at $525 \mathrm{~nm}$ and $98.0 \%$ at $620 \mathrm{~nm}$, respectively at nZVI dosage of $0.3 \mathrm{~g} / \mathrm{L}$ and initial $\mathrm{pH}$ of 3 after 180 minutes of reaction time at $25 \circ \mathrm{C}$. Moreover, the maximum COD removal efficiency obtained under these conditions was $86 \%$.
\end{abstract}

\section{INTRODUCTION}

Over the last few decades, rapid urbanization and industrialization have given rise to severe environmental issues, especially water pollution [1]. The water pollution is one of the major ecological issues, which threats life of all living organisms [2]. Therefore, the water pollution has received great attention all over the world [3]. In general, the water pollution is related to the human activities [2]. Most of the water resources are polluted due to industrial activities [4]. Among industrial activities, textile industry requires special attention due to high water consumption and utilization of a variety of dyes and chemicals [5-6]. In comparison to other industries, the textile industry is the second sector in water usage in Turkey and also has a significant percentage in economy in accordance with trade statistics [7]. A normal textile industry usually uses water of approximately 1.6 million $\mathrm{L}$ to manufacture around $8000 \mathrm{~kg}$ of textile fabric per day $[3,8]$. The wet fabric industries generate large amounts of wastewater owing to the use of high amounts of water in desizing, cleaning, bleaching, mercerizing, dyeing, printing and finishing [6]. During the dyeing process, not all the dyes are fixed to the fabrics. There is always a portion of unfixed dye which gets washed away along with water that forms the main pollutant in textile effluent [9]. The other components such as acids, alkalis, starch, various surfactants, catalytic chemicals, cleaning solvents, $\mathrm{NaCl}, \mathrm{Na}_{2} \mathrm{SO}_{4}$ and soaps of metals are also included in wastewater [5].

Wastewater generated from these industries should be well managed and treated owing to high color, high oxygen demand and large amount of total dissolved and suspended solids [3]. Particularly, these effluents change quality of water bodies [10]. The discharge into rivers and lakes of these effluents can lead to undesirable consequences such as foaming, thermal effect, color problem and unpleasant aesthetic appearance [11]. They inhibit the photosynthesis activity by the reducing the passage of light through water, 
change the natural balance of flora and fauna and thus adversely affect the aquatic life [12-13]. In addition, it is poisonous, mutagenic and carcinogenic owing to its dye context [14]. When these effluents reach into the water table, groundwater quality also deteriorates [10]. Because large amounts of the effluents have been discharged from the textile factories, development of effective treatment methods is essential to lower the detrimental impacts of pollutants [2].

The conventional and advanced treatment methods such as flocculation, Fenton oxidation, membrane filtration, adsorption, phytoremediation, bioremediation, photochemical, ion exchange, electrochemical oxidation, electrolytic precipitation, and ozonation have been used for treatment of textile dyeing industry effluents. They have one and more limitations including high cost of chemical coagulants and adsorbents, membrane fouling, sludge production and disposal issue, transfer of contaminants from one phase to another, inhibition of bacterial growth and generation of secondary pollutants during the process application [10]. Although biological processes are economic, simple and environmentally friendly alternatives [3,15], the textile dyes are difficult to biodegrade owing to their synthetic origin and complex structure [14,16-18]. Furthermore, biological processes are necessary long time and high energy for treatment [15]. For this reason, it is necessary to use different methods in which the dyes are mineralized or converted into more biodegradable substances [19].

Nanoparticles have been studied on the removal of various contaminants due to sorption and redox capacity. Nanoparticles such as nano-zero iron (nZVI), nZVI/Pd bimetallic, titania, zinc oxide and carbon nanotubes were previously used on the removal of contaminants [20]. Recently, nZVI has great attention in many studies for the removal of contaminants such as halogenated organics, heavy metals, pesticides, dyes, nitroaromatic compounds and nitrates due to high specific surface area and the ability to reduce pollutants [2131]. On the other hand, nZVI is environmentally friendly, highly reactive and low cost [32]. The reaction between nZVI particles and dye molecules plays a significant role for the removal of dyes. In this reaction, the nZVI donates electrons and dye molecules receive electrons, i.e. nZVI particles are oxidized to $\mathrm{Fe}^{2+}$ and $\mathrm{Fe}^{3+}$ ions and the hydroxyl, hydrogen ion formed react with dye molecules to disrupt chromophore bond. As a result, partial mineralization and complete degradation have been achieved. The dye removal by nZVI particles depends on parameters such as $\mathrm{pH}$, the nanoscale zero-valent iron amount, dye concentration and volume [10].

Many researches have been done on treatment of synthetically prepared industrial wastewater. However, it is difficult to treat real textile wastewater because it has a complex composition and variety [33]. In this study, color and COD removals from real textile wastewater by nZVI particles were studied. The effects of $\mathrm{pH}, \mathrm{nZVI}$ dosage and temperature on color and COD removals were investigated.

\section{MATERIALS AND METHODS}

\subsection{Real Textile Wastewater}

Real wastewater from the rinse tanks of the indigo dyeing process of a denim production factory (Malatya, Turkey) was used in this study. Characterization of the real wastewater is shown in Table 1. It was kept in the refrigerator at $+4{ }^{\circ} \mathrm{C}$ to prevent any possible change of wastewater properties.

Table 1. Properties of real textile wastewater used in this study

\begin{tabular}{lll}
\hline Parameter & Unit & Values \\
\hline $\mathrm{pH}$ & & $10.35-10.39$ \\
$\mathrm{COD}$ & $\mathrm{mg} / \mathrm{L}$ & $295-315$ \\
Color & & \\
$-436 \mathrm{~nm}$ & $\mathrm{~m}^{-1}$ & $44.0-62.3$ \\
$-525 \mathrm{~nm}$ & $\mathrm{~m}^{-1}$ & $40.0-53.3$ \\
$-620 \mathrm{~nm}$ & $\mathrm{~m}^{-1}$ & $61.0-88.8$ \\
\hline
\end{tabular}




\subsection{Batch Experiments}

Batch experiments were carried out in 250-mL Erlenmeyer flasks containing $100 \mathrm{~mL}$ of real textile wastewater. The initial pHs were adjusted by adding diluted $\mathrm{H}_{2} \mathrm{SO}_{4}$ or $\mathrm{NaOH}$ using a digital $\mathrm{pH}$-meter (Orion 3 STAR). The experiments were carried out in an orbital shaker (Gallenkamp) at $160 \mathrm{rpm}$ shaking speed.

\section{3. nZVI Synthesis and Characterization}

The synthesis of nZVI particles used in this study was carried out by using the borohydride reduction method [34]. It was prepared in the laboratory in four open-necked $500 \mathrm{~mL}$ bottles. The solution was mixed strongly with a mechanical stirrer $(250 \mathrm{rpm})$. To reduce ferric ions to nZVI, borohydride solution (358.5 $\left.\mathrm{mM} \mathrm{BH}_{4}^{-}\right)$of $250 \mathrm{~mL}$ was added with a constant delivery rate of $20 \mathrm{~mL} / \mathrm{min}$ into ferric ion $\left(\mathrm{Fe}^{3+}\right)$ solution $\left(71.7 \mathrm{mM} \mathrm{Fe}^{3+}\right)$ of $250 \mathrm{~mL}$ from one of the necks on side of the flask reactor. Nitrogen gas was used to hinder iron oxidation, and the inlet and outlet of gas were provided by the other two necks of the flask. This reaction is described as follows:

$4 \mathrm{Fe}^{3+}+3 \mathrm{BH}_{4}^{-}+9 \mathrm{H}_{2} \mathrm{O} \rightarrow 4 \mathrm{Fe}^{\mathrm{o}}+3 \mathrm{H}_{2} \mathrm{BO}_{3}{ }^{-}+12 \mathrm{H}^{+}+6 \mathrm{H}_{2}$.

The particle size and morphology were determined using scanning electron microscopy (Jeol-JSM-7001F) at voltage of $15 \mathrm{kV}$.

\subsection{COD and Color Measurements}

COD measurements were determined by applying open reflux methods [35]. The absorbance values of the samples at $436 \mathrm{~nm}, 525 \mathrm{~nm}$ and $620 \mathrm{~nm}$ wavelengths were measured by a UV/Vis spectrophotometer (Perkin Elmer Lambda 25) and then color measurements were expressed as the spectral absorption coefficient (SAC). In this way, the spectral absorption coefficient values were accounted by using the following relationship:

$\operatorname{SAC}\left(m^{-1}\right)=\frac{A(\lambda)}{d}$.

In Equation (2), $\mathrm{A}$ is the absorbance of the sample and $\mathrm{d}$ is the path length $(0.01 \mathrm{~m})$.

\section{RESULTS AND DISCUSSION}

\subsection{Characterization of nZVI}

The X-ray diffractogram and FTIR spectra of nZVI particles were reported in detail in our previous study [36]. The surface morphology and elemental composition of synthesized nanoparticles were investigated by an SEM-EDX and are presented in Figure 1. As seen from SEM images, the nZVI particles had spherical shape and chain-like structures. The sizes of nZVI particles were mostly in the range of $40-100 \mathrm{~nm}$. This structure can be formed due to the magnetic interactions of inter-particle van der Waals forces [34]. The similar chain-like structure has also been reported in other studies. For example, Sawafta and Shahwan [37] and Fang et al. [38] reported the chain-like structures. According to SEM-EDX analysis, the nanoparticle consists mostly of iron (92\%).

\subsection{Effect of Initial pH}

The behavior of adsorbent is highly dependent on the $\mathrm{pH}$ value of aqueous solution, as $\mathrm{pH}$ highly changes the surface charge, ionization degree and existence species of adsorbent [39]. The effect of $\mathrm{pH}$ was studied at different $\mathrm{pH}$ values ranging from 2 to 9 with nZVI dosage of $0.2 \mathrm{~g} / \mathrm{L}$. The results obtained are illustrated in Figures 2, 3 and 4. The color removal efficiencies increased as $\mathrm{pH}$ decreased. The maximum color removal efficiencies were determined at $\mathrm{pH}$ of 3.0 at 436,525 and $620 \mathrm{~nm}$ wavelengths after $180 \mathrm{~min}$. The 
lowest spectral absorption coefficient values were $2.3 \mathrm{~m}^{-1}$ at $436 \mathrm{~nm}, 0.9 \mathrm{~m}^{-1}$ at $525 \mathrm{~nm}$ and $1.0 \mathrm{~m}^{-1}$ at 620 $\mathrm{nm}$ at initial $\mathrm{pH}$ of 3 . The lowest color removal efficiencies were $11 \%$ at $436 \mathrm{~nm}, 4 \%$ at $525 \mathrm{~nm}$ and $0.5 \%$ at $620 \mathrm{~nm}$ within $180 \mathrm{~min}$ at $\mathrm{pH} \mathrm{9,} \mathrm{while} \mathrm{the} \mathrm{maximum} \mathrm{color} \mathrm{removal} \mathrm{efficiencies} \mathrm{were} 98 \%$ at $436 \mathrm{~nm}$, $99.2 \%$ at $525 \mathrm{~nm}$ and $99.5 \%$ at $620 \mathrm{~nm}$ within $180 \mathrm{~min}$ at $\mathrm{pH}$ of 3. As seen in Figure 4, COD removal efficiencies within $180 \mathrm{~min}$ at $\mathrm{pH} 2,3,4,5,6,7,8$ and 9 were 49.2, 76.2, 41.3, 47.6, 47.6, 50.8, 41.3 and $19.0 \%$, respectively. The maximum COD removal $(76 \%)$ was observed at $\mathrm{pH}$ of 3 . Based on both color and $\mathrm{COD}$ removal, $\mathrm{pH}$ of 3 appears to be optimal. Figures also show that solution $\mathrm{pH}$ had an adverse effect on the removal when $\mathrm{pH}$ ranged from 4 to 9 .

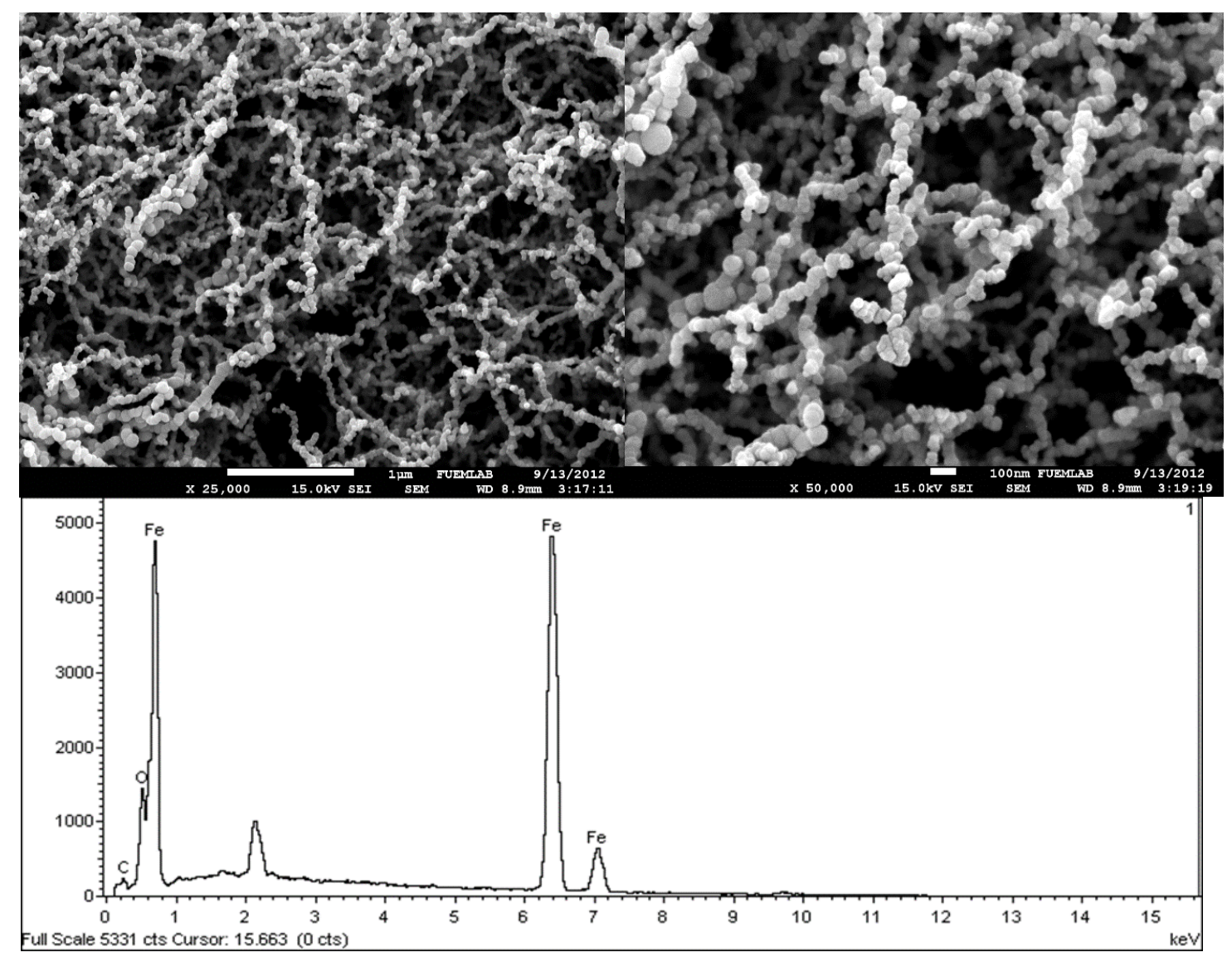

Figure 1. SEM-EDX images of the synthesized $n Z V I$

This phenomenon can be attributed to positively charged adsorbent and negatively charged dye molecules when $\mathrm{pH}$ was below the $p H_{p z c}(\approx 5.38)$. Since $p H_{p z c}$ value of nZVI was determined to be 5.38 [34]. Therefore, electrostatic interaction occurs. This result may also be described that more hydrogen ions were released at acidic $\mathrm{pH}$ values. In this case, they can speed up the corrosion of nanoparticle, and remove iron (II) hydroxide from the nanoparticle surface to create fresh active sites. At alkaline $\mathrm{pH}$ values, hydroxly ions will remarkably increase the generation of the iron hydroxide on the nZVI surface and dye removal efficiency will decrease [27, 40-42]. Furthermore, low removal efficiency of dye was observed at an extremely acidic ( $\mathrm{pH}$ : 2) condition, possibly due to the rapid dissolution of the nZVI particles in bulk solution [40].

Similar results have been observed in studies of removing several dyes and organic contaminants by nZVI. Fang et al. [38] studied metronidazole removal using nanoparticle and reported that metronidazole removal increased as the pH decreased. Similarly, Satapanajaru et al. [43] studied the effectiveness of nanoparticle to remove two types of dyes and stated that dye removal was $100 \%$ for two dyes at $\mathrm{pH}$ of 3 . 

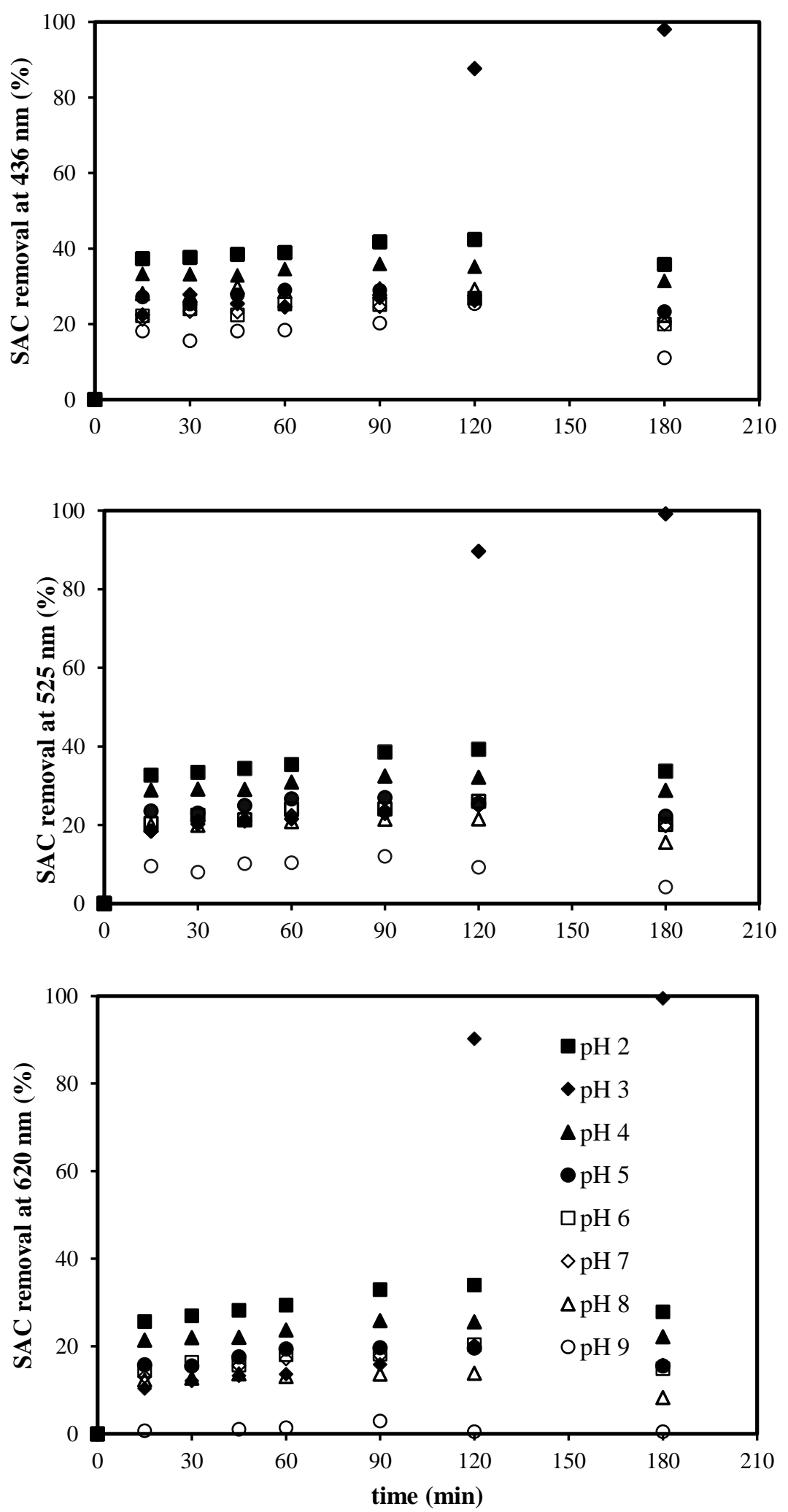

Figure 2. Effect of pH on color removal (nZVI: $0.2 \mathrm{~g} / \mathrm{L}, \mathrm{T:25}{ }^{\circ} \mathrm{C}$ ) 


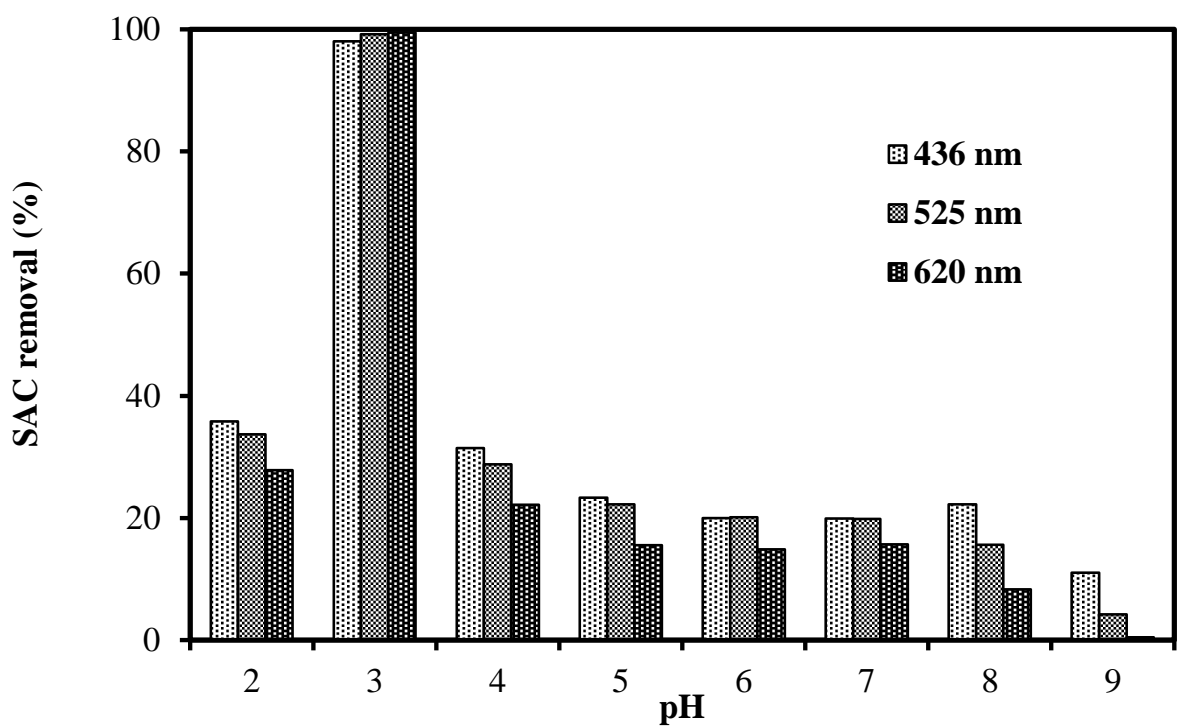

Figure 3. Comparative representation of pH effect on color removal ( $\mathrm{nZVI}: 0.2 \mathrm{~g} / \mathrm{L}, \mathrm{T:25}{ }^{\circ} \mathrm{C}$ )

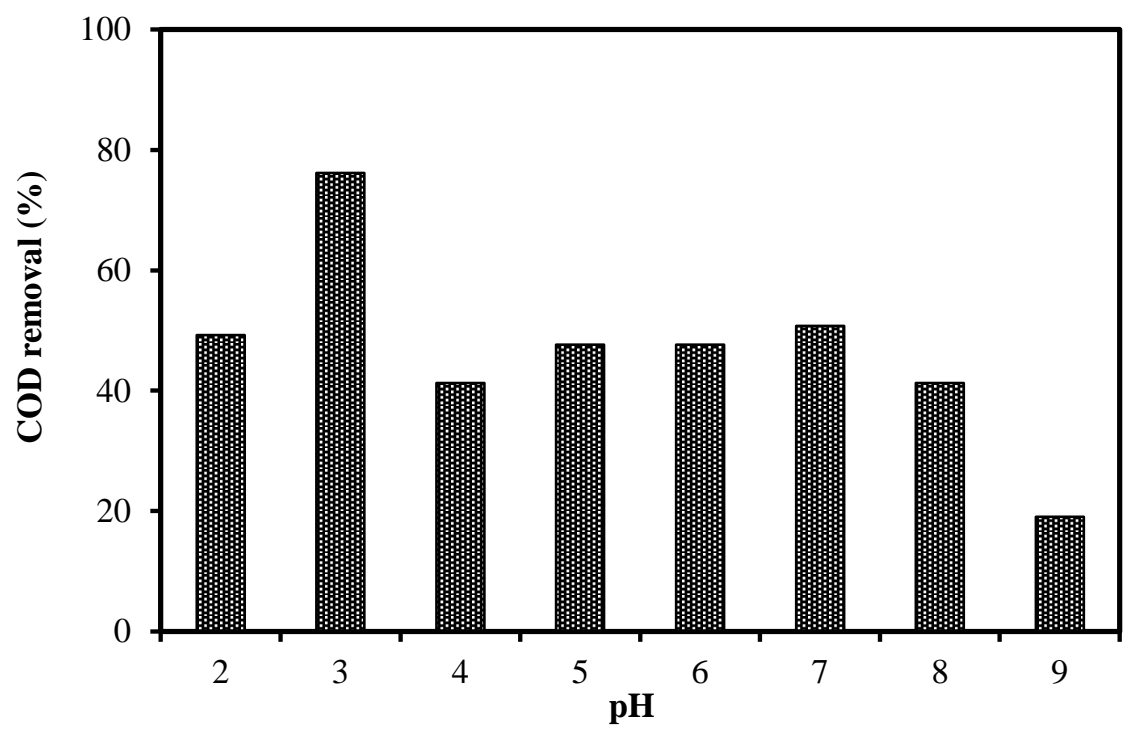

Figure 4. Effect of pH on COD removal (nZVI: $0.2 \mathrm{~g} / \mathrm{L}, \mathrm{T}: 25^{\circ} \mathrm{C}$ )

\subsection{Effect of nZVI Dosage}

The amount of nZVI is one of the most important factors for effective color removal efficiency. The results obtained from the experiments performed by applying nZVI at concentrations in the range of $0.1-0.6 \mathrm{~g} / \mathrm{L}$ at $\mathrm{pH}$ of 3 are given in Figures 5 and 6 . With the increasing amount of nZVI, color removal efficiencies increased. It provides a larger surface activity area to collide with dye molecules by using more nZVI. This is described both the increase in the nZVI surface area and the enhancement in the number of available active sites. Hence, this accelerates the dye removal efficiency. At a nZVI dosage of $0.1 \mathrm{~g} / \mathrm{L}$, after $180 \mathrm{~min}$, the color removal efficiency was determined as $35.4 \%$ at $436 \mathrm{~nm}, 39.3 \%$ at $525 \mathrm{~nm}$ and $27.9 \%$ at $620 \mathrm{~nm}$ while the COD removal efficiency was $42.9 \%$. At a nZVI dosage of $0.2 \mathrm{~g} / \mathrm{L}$, after $180 \mathrm{~min}$, the color removal efficiency was determined as $98.0 \%$ at $436 \mathrm{~nm}, 99.2 \%$ at $525 \mathrm{~nm}$ and $99.5 \%$ at $620 \mathrm{~nm}$. At a nZVI dosage of $0.3 \mathrm{~g} / \mathrm{L}$, the color removal efficiencies were determined as $96.3 \%$ at $436 \mathrm{~nm}, 97.8 \%$ at $525 \mathrm{~nm}$ and $98.0 \%$ at $620 \mathrm{~nm}$ within $180 \mathrm{~min}$. On the other hand, a sharp increase in color removal efficiency occurred in a shorter time when $\mathrm{nZVI}$ of $0.3 \mathrm{~g} / \mathrm{L}$ was used. Color removal efficiencies were $22.4 \%$ at 436 $\mathrm{nm}, 18.5 \%$ at $525 \mathrm{~nm}$ and $10.3 \%$ at $620 \mathrm{~nm}$ within $15 \mathrm{~min}$ when nZVI of $0.2 \mathrm{~g} / \mathrm{L}$ were used, while color removal efficiencies were $68.6 \%$ at $436 \mathrm{~nm}, 74.1 \%$ at $525 \mathrm{~nm}$ and $74.4 \%$ at $620 \mathrm{~nm}$ within 15 min when 
nZVI of $0.3 \mathrm{~g} / \mathrm{L}$ were used. After 30 minutes of reaction time, the color removal efficiencies increased to $91.0 \%$ at $436 \mathrm{~nm}, 91.8 \%$ at $525 \mathrm{~nm}$ and $92.8 \%$ at $620 \mathrm{~nm}$. The usage of nZVI more than $0.3 \mathrm{~g} / \mathrm{L}$ was unnecessary as the color and COD removal efficiencies are close to each other. For instance, COD removal efficiency was $76 \%$ at nZVI dosage of $0.2 \mathrm{~g} / \mathrm{L}$, and $86 \%$ at nZVI dosages of 0.3 and $0.4 \mathrm{~g} / \mathrm{L}$. This can be described by the fact that most of the dye molecules in the medium are adsorbed and there is not enough dye molecules in the medium. Based on these results, the optimum amount of nZVI was determined to be $0.3 \mathrm{~g} / \mathrm{L}$. Shu et al. [26] performed a feasibility study for removing Acid Black 24 by the nZVI and reported that the amount of nZVI exponentially increases the efficiency. Xia et al. [44] stated that the chloramphenicol removal was significantly increased with increasing nZVI and reported that this increase was owing to the catalytic reduction occurring at the nZVI surface and the increased surface area for the adsorption and reaction sites.
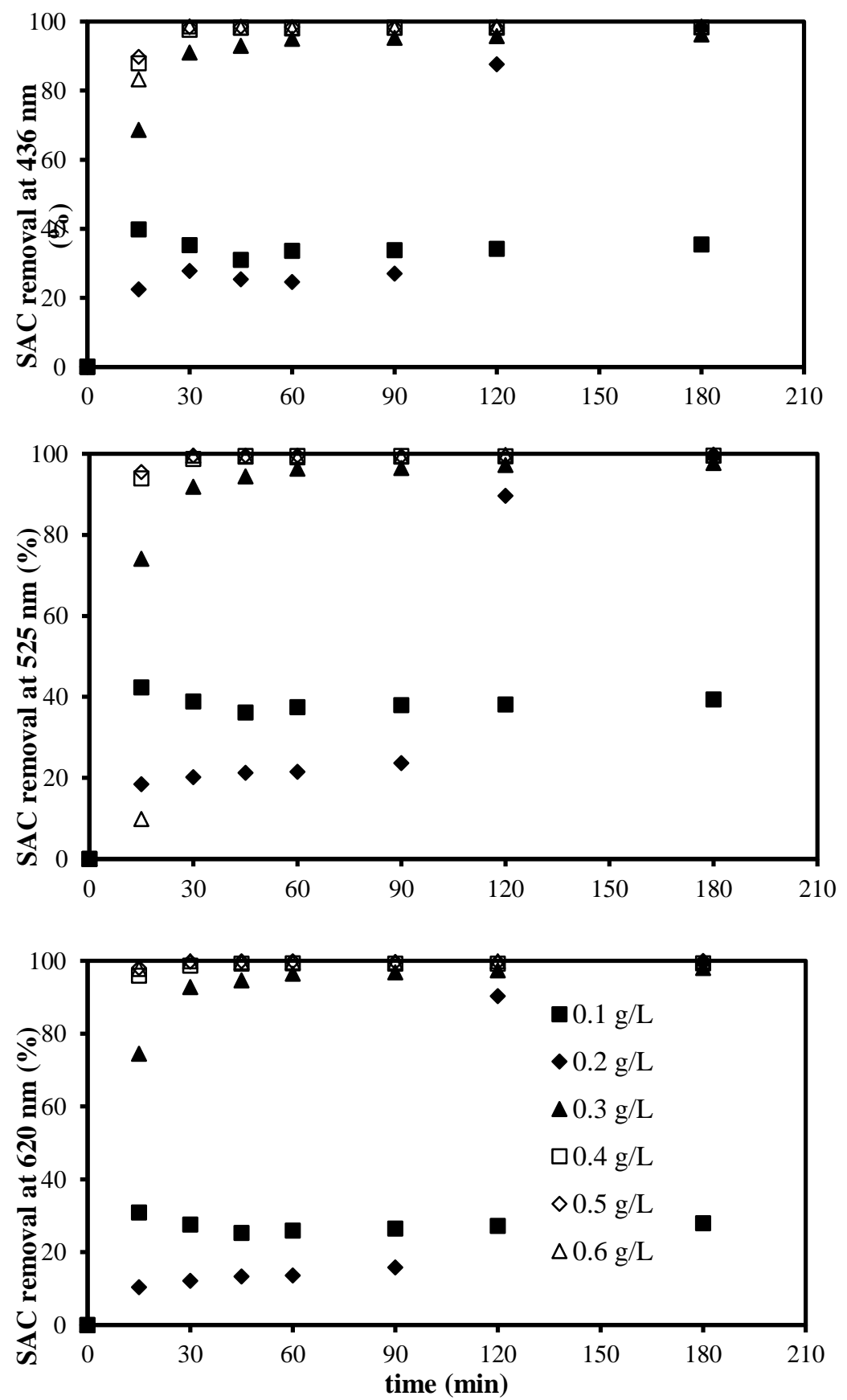

Figure 5. Effect of $n Z V I$ dosage on color removal ( $p H: 3, T: 25^{\circ} \mathrm{C}$ ) 

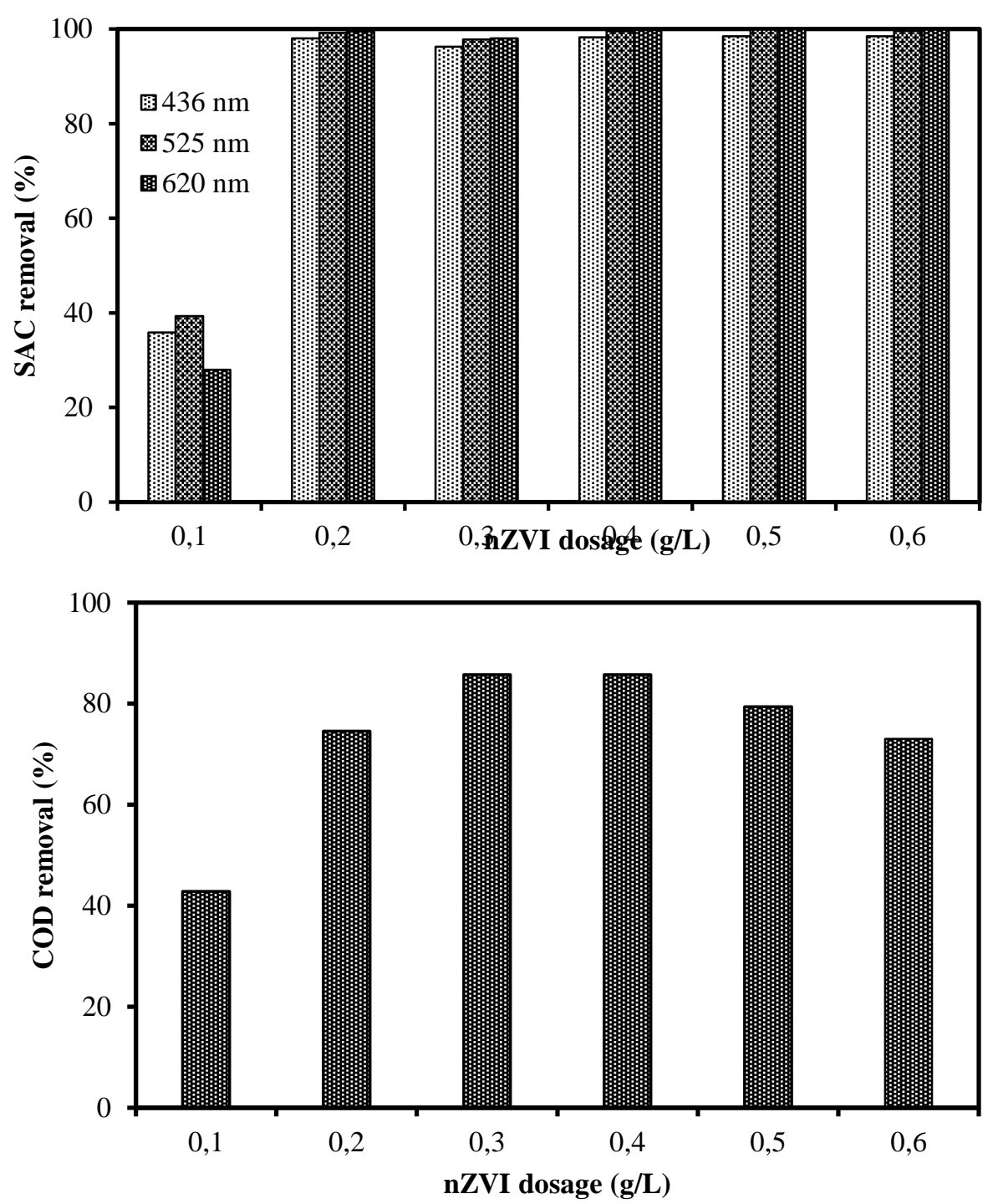

Figure 6. Comparative representation of effect of $n Z V I$ dosage on color removal and effect of $n Z V I$ dosage on COD removal ( $\left.\mathrm{pH}: 3, \mathrm{T:25}{ }^{\circ} \mathrm{C}\right)$

\subsection{Effect of Temperature}

The effect of temperature on color and COD removal from real textile wastewater with nZVI was investigated at 25,35 and $45^{\circ} \mathrm{C}$. The experiments were run at nZVI dosage of $0.3 \mathrm{~g} / \mathrm{L}$ and initial $\mathrm{pH}$ of 3 . The variation of color removal efficiency with temperature is illustrated in Figures 7 and 8 . As can be seen from the Figure 7, there is no significant difference among the removal efficiencies depending on the temperature increase within $180 \mathrm{~min}$. For example, after 180 minutes of reaction time at 25,35 and $45{ }^{\circ} \mathrm{C}$, the color removal efficiencies were $96.3 \%, 95.2 \%$ and $94.8 \%$ at $436 \mathrm{~nm}, 97.8 \%, 97.0 \%$ and $96.5 \%$ at 525 $\mathrm{nm}$, and $98.0 \%, 97.7 \%$ and $97.3 \%$ at $620 \mathrm{~nm}$, respectively. Moreover, the color removal efficiencies were $77.9 \%$ at $436 \mathrm{~nm}, 80.9 \%$ at $525 \mathrm{~nm}$ and $81.5 .3 \%$ at $620 \mathrm{~nm}$ within $20 \mathrm{~min}$ at $25{ }^{\circ} \mathrm{C}$. The color removal efficiencies increased to 91.2 and $90.7 \%$ at $436 \mathrm{~nm}, 92.4$ and $93.8 \%$ at $525 \mathrm{~nm}$ and 92.6 and $94.4 \%$ at 620 $\mathrm{nm}$ within $20 \mathrm{~min}$ at 35 and $45{ }^{\circ} \mathrm{C}$, respectively. This can be described by the increased mobility of dye molecules from the solution to the nZVI particles with increasing of temperature. Therefore, it can be stated that increased temperature caused a shortening of the required reaction time and an increase in the reaction rate. The COD removal efficiencies obtained at 25,35 and $45{ }^{\circ} \mathrm{C}$ were determined as $86 \%, 83 \%$ and $83 \%$, respectively. Similar findings were previously reported by Chen et al. [45] in the removal of methyl orange with bentonite-supported nZVI. 

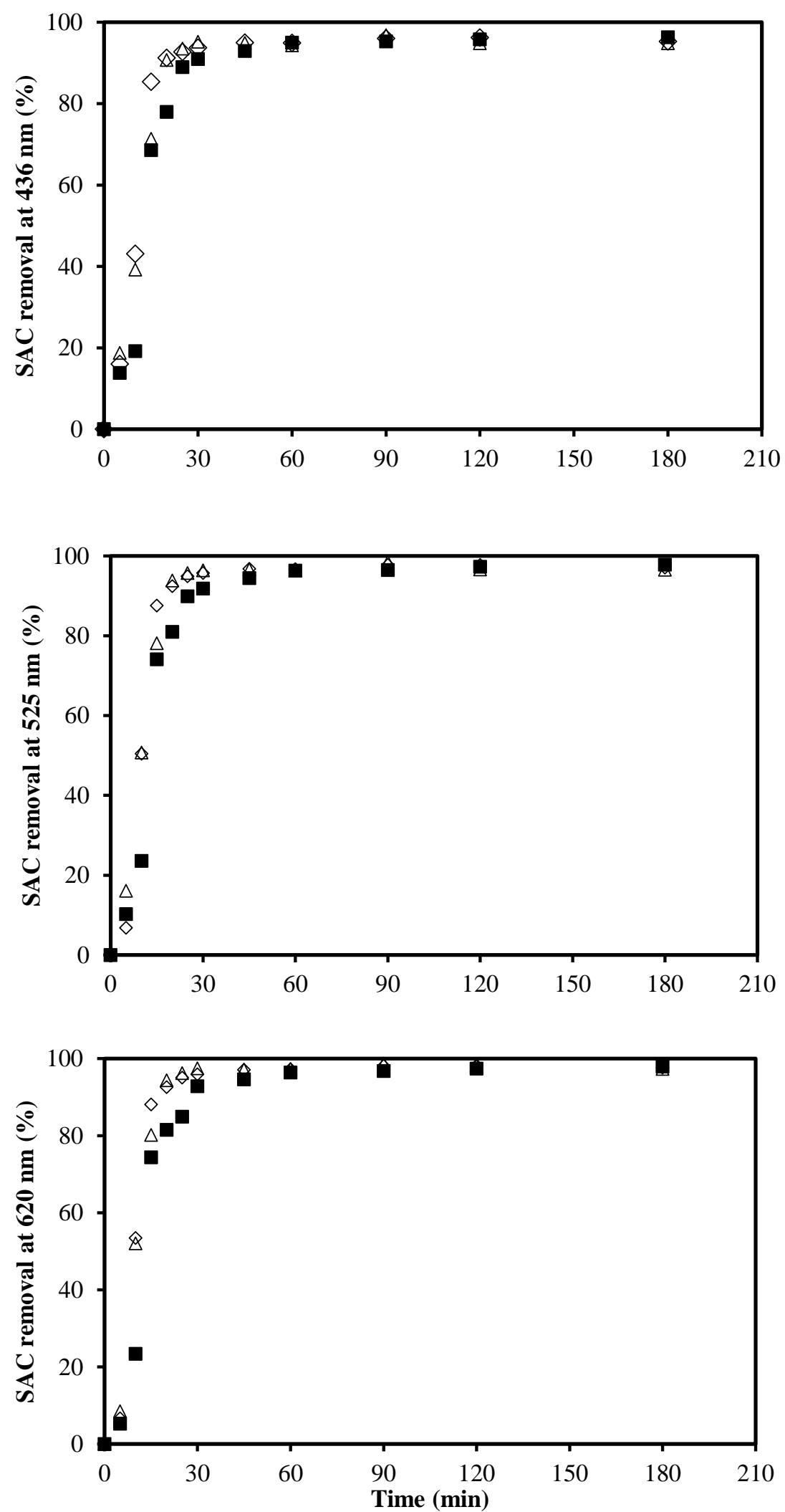

Figure 7. Effect of temperature on color removal ( $p H: 3, n Z V I: 0.3 \mathrm{~g} / \mathrm{L}$, $\mathbf{\square}: 25^{\circ} \mathrm{C}, \diamond: 35^{\circ} \mathrm{C}, \Delta: 45^{\circ} \mathrm{C}$ ) 


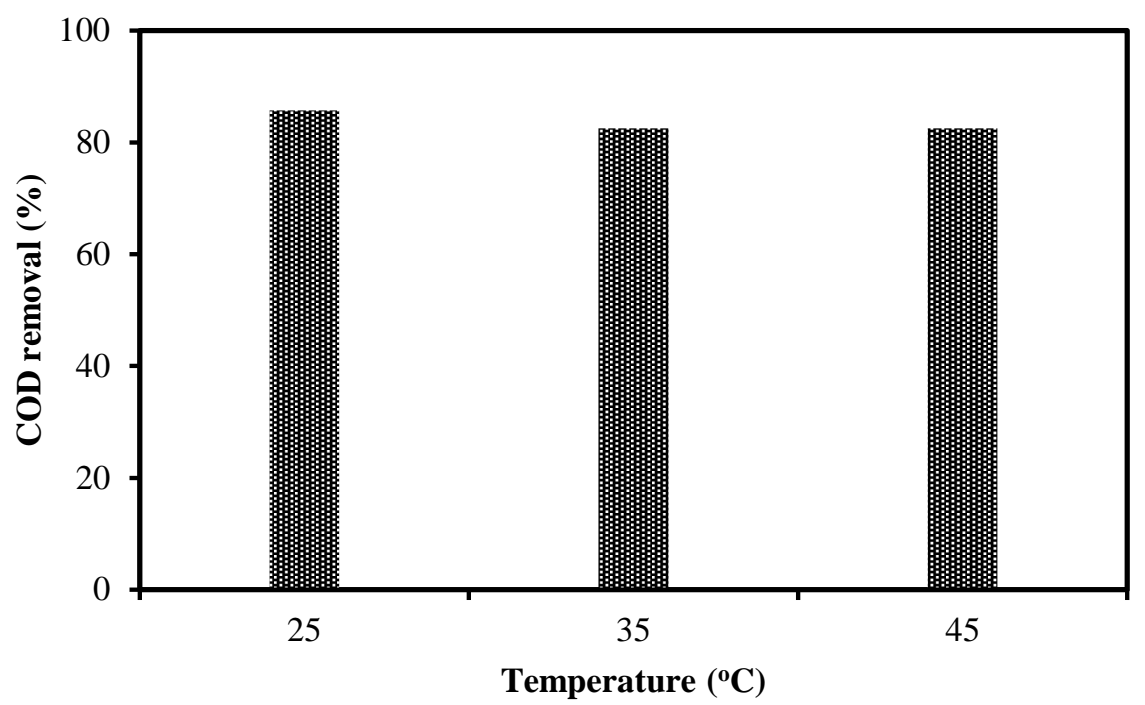

Figure 8. Effect of temperature on COD removal ( $p H: 3, n Z V I: 0.3 \mathrm{~g} / \mathrm{L}$ )

\section{CONCLUSIONS}

nZVI was used to treat real textile wastewater in this study. The solution $\mathrm{pH}$ of 3 is more effective for the removals of color and COD. However, $\mathrm{pH}$ adjustment is required after the treatment of the real textile wastewater by the nZVI and may be done by using lime. The lime is significantly cost effective compared to sodium hydroxide. Alternatively, wastewater generated during the mercerizing process in textile facility and typically containing waste chemicals such as alkali and sodium hydroxide may be used for neutralization. The current study showed that the removal efficiency increased when the nZVI dosage was increased and the temperature had a minor effect on the removal of color and COD for real textile wastewater. In this study, it may also be concluded that nZVI can be an excellent alternative to treat real textile wastewater.

\section{CONFLICTS OF INTEREST}

No conflict of interest was declared by the authors.

\section{REFERENCES}

[1] Ouyang, J., Zhou, L., Liu, Z., Heng, J.Y.Y., Chen, W., "Biomass-derived activated carbons for the removal of pharmaceutical mircopollutants from wastewater: A review", Separation and Purification Technology, 253: 117536, (2020).

[2] Bulca, Ö., Palas, B., Atalay, S., Ersöz, G., "Performance investigation of the hybrid methods of adsorption or catalytic wet air oxidation subsequent to electrocoagulation in treatment of real textile wastewater and kinetic modelling”, Journal of Water Process Engineering, 40,101821, (2021).

[3] Ceretta, M.B., Vieira, Y., Wolski, E.A., Foletto, E.L., Silvestri, S., "Biological degradation coupled to photocatalysis by $\mathrm{ZnO} /$ polypyrrole composite for the treatment of real textile wastewater", Journal of Water Process Engineering, 35: 101230, (2020).

[4] Bezirhan Arikan, E., Isik, Z., Bouras, H.D., Dizge, N., "Investigation of immobilized filamentous fungi for treatment of real textile industry wastewater using up flow packed bed bioreactor", Bioresource Technology Reports, 7: 100197, (2019). 
[5] Tavangar, T., Jalali, K., Shahmirzadi, M.A.A., Karimi, M., "Toward real textile wastewater treatment: Membrane fouling control and effective fractionation of dyes/inorganic salts using a hybrid electrocoagulation-Nanofiltration process", Separation and Purification Technology, 216: 115-125, (2019).

[6] Sharma, A., Syed, Z., Brighu, U., Gupta, A.B., Ram, C., "Adsorption of textile wastewater on alkali-activated sand", Journal of Cleaner Production, 220: 23-32, (2019).

[7] Bayrakdar, M., Atalay, S., Ersöz, G., "Efficient treatment for textile wastewater through sequential photo Fenton-like oxidation and adsorption processes for reuse in irrigation", Ceramics International, 47(7), 9679-9690, (2021).

[8] Kishor, R., Purchase, D., Saratale, G.D., Saratale, R.G., Ferreira, L.F.R., Bilal, M., Chandra, R., Bharagava, R.N., "Ecotoxicological and health concerns of persistent coloring pollutants of textile industry wastewater and treatment approaches for environmental safety", Journal of Environmental Chemical Engineering, 9: 105012, (2021).

[9] Al-Degs, Y., Khraisheh, M.A.M., Allen, S.J., Ahmad, M.N., "Effect of carbon surface chemistry on the removal of reactive dyes from textile effluent", Water Research, 34: 927-935, (2000).

[10] Raman, C.D., Kanmani, S., "Textile dye degradation using nano zero valent iron: A review", Journal of Environmental Management, 177: 341-355, (2016).

[11] He, S., Sun, W., Wang, J., Chen, L., Zhang, Y., Yu, J., "Enhancement of biodegradability of real textile and dyeing wastewater by electron beam irradiation", Radiation Physics and Chemistry, 124: 203-207, (2016).

[12] Bougdour, N., Tiskatine, R., Bakas, I., Assabbane, A., "Photocatalytic degradation of industrial textile wastewater using $\mathrm{S}_{2} \mathrm{O}_{8}{ }^{2-} / \mathrm{Fe}^{2+}$ process", Materials Today: Proceedings, 22: 69-72, (2020).

[13] Collivignarelli, M.C., Abbà, A., Miino, M.C., Damiani, S., "Treatments for color removal from wastewater: State of the art", Journal of Environmental Management, 236: 727-745, (2019).

[14] Khatri, J., Nidheesh, P.V., Anantha Singh, T.S., Suresh Kumar, M., "Advanced oxidation processes based on zero-valent aluminium for treating textile wastewater", Chemical Engineering Journal, 348: 67-73, (2018).

[15] Kaur, P., Kushwaha, J.P., Sangal, V.K., "Electrocatalytic oxidative treatment of real textile wastewater incontinuous reactor: Degradation pathway and disposability study", Journal of Hazardous Materials, 346: 242-252, (2018).

[16] Sahinkaya, E., Uzal, N., Yetis, U., Dilek, F.B., "Biological treatment and nanofiltration of denim textile wastewater for reuse", Journal of Hazardous Materials, 153: 1142-1148, (2008).

[17] Nakhate, P.H., Gadipelly, C.R., Joshi, N.T., Marathe, K.V., "Engineering aspects of catalytic ozonation for purification of real textile industry wastewater at the pilot scale", Journal of Industrial and Engineering Chemistry, 69: 77-89, (2019).

[18] Domingues, F.S., Geraldino, H.C.L., de Souza Freitas, T.K.F., de Almeida, C.A., de Figueiredo, F.F., Garcia, J.C., "Photocatalytic degradation of real textile wastewater using carbon black- $\mathrm{Nb}_{2} \mathrm{O}_{5}$ composite catalyst under UV/Vis irradiation", Environmental Technology, 42(15): 2335-2349, (2021). DOI : org/10.1080/09593330.2019.1701565 
[19] Asgari, G., Shabanloo, A., Salarib, M., Eslami, F., "Sonophotocatalytic treatment of AB113 dye and real textile wastewater using $\mathrm{ZnO} /$ persulfate: Modeling by response surface methodology and artificial neural network", Environmental Research, 184: 109367, (2020).

[20] Ravikumar, K.V.G., Santhosh, S., Sudakaran, S.V., Nancharaiah, Y.V., Mrudula, P., Chandrasekaran, N., Mukherjee, A., "Biogenic nano zero valent iron (Bio-nZVI) anaerobic granules for textile dye removal", Journal of Environmental Chemical Engineering, 6: 1683-1689, (2018).

[21] Song, H., Carrway, E.R., "Reduction of chlorinated ethanes by nanosized zero-valent iron: kinetics, pathways, and effects of reaction condition", Environmental Science \& Technology, 39, 6237-6245, (2005).

[22] Üzüm, C., Shahwan, T., Eroğlu, A.E., Lieberwirth, I., Scott, T.B., Hallam, K.R., "Application of zero-valent iron nanoparticles for the removal of aqueous $\mathrm{Co}^{2+}$ ions under various experimental conditions", Chemical Engineering Journal, 144: 213-220, (2008).

[23] Efecan, N., Shahwan, T., Eroğlu, A.E., Lieberwirth, I., "Characterization of theuptake of aqueous $\mathrm{Ni}^{2+}$ ions on nanoparticles of zero-valent iron (nZVI)", Desalination, 249: 1048-1054, (2009).

[24] Xi, Y., Mallavarapu, M., Naidu, R., "Reduction and adsorption of $\mathrm{Pb}^{2+}$ in aqueous solution by nano-zero-valent iron-A SEM, TEM and XPS study", Materials Research Bulletin, 45: 13611367, (2010).

[25] Satapanajaru, T., Anurakpongsatorn, P., Pengthamkeerati, P., Boparai, H., "Remediation of atrazine-contaminated soil and water by nano zerovalent iron", Water Air and Soil Pollution, 192: 349-359, (2008).

[26] Shu, H.-Y., Chang, M.-C., Yu, H.-H., Chen, W. H., "Reduction of an azo dye Acid Black 24 solution using synthesized nanoscale zerovalent iron particles", Journal of Colloid and Interface Science, 314: 89-97, (2007).

[27] Sohrabi, M.R., Amiri, S., Masoumi, H.R.F., Moghri, M., "Optimization of Direct Yellow 12 dye removal by nanoscale zero-valent iron using response surface methodology", Journal of Industrial and Engineering Chemistry, 20: 2535-2542, (2014).

[28] Sohrabi, M.R., Moghri, M., Masoumi, H.R.F., Amiri, S., Moosavi, N., "Optimization of Reactive Blue 21 removal by nanoscale zero-valent iron using response surface methodology", Arabian Journal of Chemistry, 9: 518-525, (2016).

[29] Ling, X.F., Li, J.S., Zhu, W., Zhu, Y.Y., Sun, X.Y., Shen, J.Y., Han, W.Q., Wang, L.J., "Synthesis of nanoscale zero-valent iron/ordered mesoporous carbon for adsorption and synergistic reduction of nitrobenzene", Chemosphere, 87: 655-660, (2012).

[30] Zhang, X., Lin, Y.M., Shan, X.Q., Chen, Z.L., "Degradation of 2,4,6-trinitrotoluene (TNT) from explosive wastewater using nanoscale zero-valent iron", Chemical Engineering Journal, 158, 566$570,(2010)$.

[31] Hwang, Y.H., Kim, D.G., Shin, H.S., "Mechanism study of nitrate reduction by nano zero valent iron", Journal of Hazardous Materials, 185: 1513-1521, (2011).

[32] Eljamal, O., Mokete, R., Matsunaga, N., Sugihara, Y., "Chemical pathways of nanoscale zerovalent ron (NZVI) during its transformation in aqueous solutions", Journal of Environmental Chemical Engineering, 6: 6207-6220, (2018). 
[33] Shoukat, R., Khan, S.J., Jamal, Y., "Hybrid anaerobic-aerobic biological treatment for real textile wastewater", Journal of Water Process Engineering, 29: 100804, (2019).

[34] Hanay, O., Turk, H., "Comprehensive evaluation of adsorption and degradation of tetracycline and oxytetracycline by nanoscale zero-valent iron", Desalination and Water Treatment, 53(7): 1986-1994, (2015).

[35] APHA, "Standard Methods for the Examination of Water and Wastewater", 17th ed., APHA, AWWA, WPCF, American Public Health Association, Washington, D.C., USA, (1989).

[36] Tunç, M.S., Tepe, O., "Removal of phenol from aqueous solution using persulfate activated with nanoscale zero-valent iron”, Desalination and Water Treatment, 74: 269-277, (2017).

[37] Sawafta, R., Shahwan, T., "A comparative study of the removal of methylene blue by iron nanoparticles from water and water-ethanol solutions", Journal of Molecular Liquids, 273: 274281, (2019).

[38] Fang, Z., Chen, J., Qiu, X., Qiu, X., Cheng, W., Zhu, L., "Effective removal of antibiotic metronidazole from water by nanoscale zero-valent iron particles", Desalination, 268: 60-67, (2011).

[39] Chen, Y., Lin, Z., Hao, R., Xu, H., Huang, C., "Rapid adsorption and reductive degradation of Naphthol Green B from aqueous solution by Polypyrrole/Attapulgite composites supported nanoscale zero-valent iron", Journal of Hazardous Materials, 371: 8-17, (2019).

[40] Dutta, S., Saha, R., Kalita, H., Bezbaruah, A.N., "Rapid reductive degradation of azo and anthraquinone dyes by nanoscale zero-valent iron", Environmental Technology \& Innovation, 5: 176-187, (2016).

[41] Weng, X., Cai, W., Lin, S., Chen, Z., "Degradation mechanism of amoxicillin using clay supported nanoscale zerovalent iron", Applied Clay Science, 147: 137-142, (2017).

[42] Zhang, B., Wang, D., "Preparation of biomass activated carbon supported nanoscale zero-valent iron (nZVI) and its application in decolorization of methyl orange from aqueous solution", Water, 11: 1671, (2019).

[43] Satapanajaru, T., Chompuchan, C., Suntornchot, P., Pengthamkeerati, P., "Enhancing decolorization of Reactive Black 5 and Reactive Red 198 during nano zerovalent iron treatment", Desalination, 266: 218-230, (2011).

[44] Xia, S., Gu, Z., Zhang, Z., Zhang, J., Hermanowicz, S.W., "Removal of chloramphenicol from aqueous solution by nanoscale zero-valent iron particles", Chemical Engineering Journal, 257: 98-104, (2014).

[45] Chen, Z.-X., Jin, X.-Y., Chen, Z., Megharaj, M., Naidu, R., "Removal of methyl orange from aqueous solution using bentonite-supported nanoscale zero-valent iron", Journal of Colloid and Interface Science, 363: 601-607, (2011). 